\title{
DOI: 10.7596/taksad.v8i3.2246
}

Citation: Akhmedova, M. N., Giniyatullina, A. J., \& Nigmatullina, A. M. (2019). Poetry 'Sacred Defense "In Modern Persian Literature. Journal of History Culture and Art Research, 8(3), 251-258. doi:http://dx.doi.org/10.7596/taksad.v8i3.2246

\section{Poetry "Sacred Defense" in Modern Persian Literature}

\author{
Mastura Negmatdzonovna Akhmedova ${ }^{1}$, Alsu Junisovna Giniyatullina², \\ Alsu Mansurovna Nigmatullina ${ }^{3}$
}

\begin{abstract}
The topicality of the problem under study is conditioned by the fact that, in the studies on Persian poetry, in contrast to previous eras, certain dynamics was noted, the dynamics which aimed at identifying the dominant trends in the development of Persian literature as a whole. The purpose of the article is to study the processes that led to the change of traditional views by the modernistic ideology; revealing the author's individuality. The public sentiment and the role of the poet at the contemporary stage, the assessment of the creative heritage and the fresh angle on the world, the relationship between the artist and the environment, philosophical ideas and personal experiences were in sight and received refraction in the artistic process. This article is a part of the history of Iranian literature from ancient times to the present day and can be used by various specialists (literary scholars, graduate students, students), as well as reading special courses on contemporary Iranian poetry.
\end{abstract}

Keywords: Religious studies, Revolution, Spirituality, culture, identity, The idea of shahadah, Military poetry, The Iran-Iraq war, Religious motives, Mysticism, National-patriotic poetry.

\footnotetext{
${ }^{1} \mathrm{PhD}$, Associate Professor of the Department of Oriental and African Studies, and Islamic Studies of the Institute of International Relations, Kazan Federal University. E-mail: ahmadova_74@mail.ru

2 PhD, Associate Professor of the Department of Department of Foreign Languages in International Relations of the Institute of International Relations, Kazan Federal University. E-mail: alsu.giniyatullina.2016@mail.ru

${ }^{3} \mathrm{PhD}$, Associate Professor of the Department of Oriental and African Studies, and Islamic Studies of the Institute of International Relations, Kazan Federal University. E-mail: alsunigmatullina@mail.ru
} 


\section{Introduction}

The processes taking place in Persian poetry show that it develops in accordance with the general laws characteristic of other world literatures. The development of democratic poetry in Iran of the XX century was marked by the strengthening of its social themes. The rapprochement between the problems of poetry and urgent social issues led to a breakdown of poetic consciousness [Akhmedova, 2018; Klyashtorina, 1975].

The poetry of "Sacred defense" devoted to the Iran-Iraq war of 1980-1988 takes special place in modern Persian literature. Many classics of modern Persian literature as Salman Heraty, Nasrollah Mardani, Sepideh Kashani, Qeysar Aminpur, Ali Musavi Garmarudi, Sayid Hassan Hoseyni, Mohammad Reza Abdolmalekiyan, and many others lived and worked at that period. Regardless of whether poetry was created in classical or new forms, the tasks it revealed were of national importance and required immediate and clear reflection. The researchers stress the fact that moral traits-more than any other mental faculty-are considered the most essential part of identity, the self, and the soul [Aminpur, 1969].

Among the features of the military and revolutionary poetry the strong passions, openness of the senses can be distinguished. Depth, expressiveness and imagery were devoid of formal tricks and revealed, mainly, the idea of shahadah, which was one of the leading in the Iranian revolution and was strongly supported by the officials. During the war it received active realization that was expressed in conducting combat operations by means of tactics of a so-called "human wave" when "pasdars and basidzh chains went under powerful gun-fire of the opponent and through their minefields". It is no coincidence that the image of a shahid, a war hero, appears in the majority of works of military poetry the second name of which sounds as "shahadah poetry". Among verses on military topics there is a set of various works both devoted to specific people, and the heroism of representatives of a certain military profession, and there are also works by means of which the generalized character of shahid is created. The last verses are the most numerous ones. Among them it is worth mentioning "Hamāseye shahid" ("The epos about shahid") by Mehrdad Avesta, "She'r-e shahādat" ("Shakhadat poetry") by M. Shakhrokhi, "Shahid" by M. Kashani, "Ghazal-e shahid" ("A gazelle about shahid") and "Bar mazāre shahid" ("On the shahid's grave") by Bahman Salehi. The mentioned works describe shahid's qualities such as absence of fear of death, courage, readiness to sacrifice for the sake of the Motherland at any moment. Recreating the appearance of Shahid and describing the fightings, the poets not only encouraged society to resist and defeat the enemy, but also described the horrors of war, the incalculable sufferings and misfortunes generated by it. Some of them, like $Q$. Aminpour in his poem "She'ri berāye jang» openly admitted that he had not imagined before what war really was, while others wrote mainly about the tragic sides of the war, which brought the pain of loss to almost every home and every family. Thus, in the poem of Hussein Israfili «Ey barādar ke be zeyārat rafte-yi» ("O brother who has gone on pilgrimage") tells about the girl who came to the grave of her brother and mourning his death. The famous poem by Abolqasem Lahuti "Vafāy be ahd» ("Faithful promise") comes to the mind. In both verses, close relatives come to the grave of a hero: sister in the work of $\mathrm{H}$. Israfili and mother in the verse of A. Lahuti. The mournful scene is highlighted by the lamentations and tears of women. However, both poems do not give the impression of hopelessness and despair. Moreover, they are filled with optimism and faith in the future. In the work of A. Lahuti a mother brings to her son's grave the news of victory and freedom and the last words of the girl, written for her by $\mathrm{H}$. Israfili - is the same the revolutionary slogan. It is noteworthy that $\mathrm{H}$. Israfili's poem was published in two languages - Azerbaijani and Persian. 


\section{Methods}

In the first half of the $80 \mathrm{~s}$, as in the 70s, the cultural factor played an important role in the political and social life of the country. The leadership of the Islamic Republic of Iran set itself the task of purposefully linking the development of culture and literature with the dominant religious and ideological doctrine and reinforces in the minds of people the inviolability of the power of Islamic tenets [Glushkova, et al, 2019]. Military poetry, considering duration of the Iran-Iraq war, is very big. During eight military years, as well as after the end of the war the set of the works united by the general topic was created. However, the reflection of this theme, the artistic methods and techniques used by the authors, were very different.

Based on the differences in the subject and content of the poetry of this period it can be divided into two groups

\section{Revolutionary-religious poetry}

The Iranian revolution had a decisive influence on poetry, which led to the deepening of religious motives in all branches of the lyrics, to the more strict and consistent reflection of the official ideology. At the same time, developing socio - political and other topics, Iranian poets were aware of their role in society, in shaping the views and attitudes of people, especially in the first years after the revolution, during the Iran - Iraqi war.

In this context, great attention is paid to religious motives, caused, on the one hand, by the Islamic nature of the revolution, on the other, due to the war with Iraq that began in 1980. Encouraging people to fight the enemy, poetry turned to the heroic past of the country, as well as the history of Islam. One of the best role models to follow in this sense was Imam Ali, who was known to be a brave and skilled warrior. The tragedy in Karbala, familiar to Iranian society, served as a clear historical illustration of the idea of shahadah, which received a special resonance during the Iran-Iraq war. The idea of Shahadah and willingness to sacrifice was associated with the name of Imam Ali.

Organically intertwined with religious poetry, Shahadah's motives were generally reflected in the years of the Iran-Iraq war of 1980-1988. Since it was the time when it was particularly necessary to demonstrate courage and heroism, readiness to sacrifice everything for the sake of achieving victory over the enemy. The thousands have died giving their lives for this noble goal. This is how the poet Sayid Hassan Hosseyni expresses it:

You are ready to die because of Husseyn's wounds

In the afternoon of Ashura this face appeared, oh my friend,

Explaining, you sleep in blood and caravan

Boiled in the vessels of your forehead my heart

In memory of you wearing a red cloak...

[Interlinear translation]

In these lines Sayid Hassan Hosseyni beautifully describes the fighters standing on the bank of a large river, full of blood, and the infinite madness, on the banks of the Karun river, the river remembering the Dajjal and Furat and thirst that the companions of the prophet and friends of Imam Hussein experienced, shedding their blood, recollect them. 
The poets of the Islamic revolution period, even in simple words used in everyday life, tried to find and use religious meaning. A vivid illustration of the above is a poem of Sayid Hassan "Ten rules of Jihad" ("Dah farmān-e jehād "):

The current heat of my friends ' nobility

Can melt the wax of swamp water.

And around the fortress of the awake,

Threads of sounds of the voice of love,

Green fortress makes sounds!...

[Interlinear translation]

In this verse, the poet praises brave, courageous people, nobility which is capable to melt the stiffened wax of marsh, dead water and to smear the water of hatred, hostility and disagreement. Their war, their battles - all their actions are in the name of God, in the name of Islam and its shrines. For these shrines they are ready to sacrifice their lives. For description and transmission of specific content of the verse Sayid Hassan Hoseini uses many religious and Islamic concepts, excerpts from the surahs and verses of the Koran, which, of course, have great impact on the reader.

Love for God, for the Creator of all things, sometimes brings a lover to a love frenzy. Such a frenzied love dissolves the lover (man) into the beloved (God). Using similar mystical (Sufi) views of Salman Herati, the singer of ideas of "sacred defense", observing dedication of fighters (Mujahideen) on the fronts of Patriotic war he compares their selfless love to the homeland with the frenzied love to the divine beginning. In his opinion, they sacrifice themselves both in the name of God and in the name of the Motherland:

Oh, martyrs, where is your home?

What is there in your hearts besides the sun?

Wash your faces with spring water,

Speaking of God lovers speech,

And the red crown of love on your heads

It should be noted that the epic essence of revolutionary poetry has two aspects. First, it is a victory and second is martyrdom. Poetry, glorifying martyrdom, in turn, is inextricably linked with the theme of grief and mourning [Kazimov, 2005].

In the 1980-ies the poetry also addresses questions of direct inner religious feelings of an individual; the author, as if re-discovers the power and eternity of God. Lyrical character in the "Gol-e Khodā" ("Flower of God") by A. Garmarudi speaks of his love to God, prays to Him their prayers. The poetic drawing of the verse acquires a Sufi shading. Here are the images of "drop" ("qatre"), aspiring to the "sea" ("daryā"), and "heart" ("del), and "soul" ("Jān"), which is very similar to the medieval Sufi lyrics. The poets repeatedly turned to mystical motives, speaking about their loyalty and love to the revolution. Although this is not classical mysticism, emotional tension and the corresponding psychological state were created. During and after revolution mystical motives in poetry were of great significance, than previously. No wonder M. Akbari characterized revolutionary poetry as a mixture of epic, mysticism and love.

Ali Mousavi Garmarudi - one of the representatives of the older generation of poets of modern Iran. His contribution to the literature of the country was significant; he played an important role in the formation of artistic and aesthetic basis of the current Persian poetry. The peak of creative activity of 
A. Garmarudi occurred in the decade embracing the late 1970s - 1980s years. In that fateful time for the country almost all his most famous poems were created.

In 1984, three new collections of his poems: "Ta nakodja" ("anywhere"), "Chaman-i Lale" and "Khatti khun" were published. Moreover, the book "Ta nakodja" was re-edited in 1986, since it had acquired immense popularity among the people.

Among his most known works it is worth mentioning a well-known ghazal titled "Khazbn" ("Autumn"), clearly show through the pain and emotions of the poet. The main character feels emotional fatigue and addresses with instructions in which disappointment in the world around is visible:

Again, make a stop in the meadow,

Stay a while in the desert, a little (lit. sometimes) in gardens.

Take to the garden a jug of wine poems and thanks to it (literally from it),

Inner heat let it sit down a bit on the edge of fall.

Learn [by example] the yellowness (i.e. withering) of a tree leaf,

Do not attach your heart to the redness and yellowness (i.e. vanity) of the world and the people of the world.

\section{National-Patriotic poetry}

The predominant component in military poetry was a direct reflection of what was happening, an open and clear message to the reader of its position, the right thought.

It should be noted that at the same time, there were works which were more poetic in spirit, semantics and imagery of which was built on the basis of allegory, perception of the surrounding through a chain of some associations. In this aspect, the remarkable poem "Soog-e lāle" ("the Sadness of the Tulip") by Ali Muallim is considered one of the best works devoted to the war. Its peculiarity is that the author does not describe the terrible events, does not mention certain people or events of the war years. The poet tells about his experiences, expresses the pain and anguish generated by the war among the people. The artistic fabric of the poem is concentrated on the images of tulips. The short lives of a flower, its insecurity symbolize the fragility and short duration of human existence. Turning to the invisible interlocutor, the poet urges them to understand the situation of those people who find themselves in the face of terrible events, like tulips in a meadow before the impending natural disasters. He also asks to realize the feelings of the author, who is witnessing the tragedy and is deeply be concerned about what is happening. In the poem of Ali Muallim there is no narrative strand. The main method of narration is the allegory which he uses talking about people who went to war, about friends, about the dead, about those who went "to where incalculable time passes."

\section{Results and Discussion}

At the present time, due to the growing interest in the spiritual roots of national cultures, spiritual literature is becoming the object of diverse researches of different types where there are philological, philosophical, historical and many others among them. Therefore, there is a need to explore it in a historical and linguistic frame [Klyashtorina, 1975]. Speaking from patriotic positions, the poetry of the war years in a historical and linguistic frame, acquired military offensive nature. The poets themselves are aware of the importance and power of words, of the need for shifting of the poetic accents in the 
direction of approaching the real situation in the country, at the centre of events. So, Q. Aminpour wrote in "Sher-i baraye jang" ("Verse for war»):

It is necessary to compose a verse lowly and bloody.

I have to compose a poem of rage,

Verse of resistance....

No less important theme of the Aminpur poetry is the theme of the protection of the Fatherland. The war imposed by Iraq brought untold misfortunes and upheavals to the people of Iran, great human and material losses. Along with this, the war caused a wave of universal patriotism and heroism, thanks to which the people of Iran had a worthy resistance to the aggressor and managed to win. His Patriotic poems, along with the works of other poets of this time, played a significant role in inspiring the people to fight, to defend their homeland and revolutionary achievements. It was at this time that the poet wrote his famous poem "the Ballad of war".

The poem is devoid of any poetic devices, and, in fact, is a description of the details of the war. The sincerity with which the poet reveals the theme impresses greatly:

Here covert

The severed head of a man,

We must search among the ruins,

To put it in the grave [Klyashtorina, 1990].

In his works he described pain and grief, suffering and struggle, self-sacrifice of young people for the sake of revolution in various spheres of life. For example:

Ze jadeha-ye khatar buy-e yal miayad,

Kasi az an suy-e marz mohal miayad.

Ze bas fereshte be tashayyo '-e lale amad-o raft

Seda-ye mobham-e barkhord-e bal miayad... [Manuchehr, 1993].

The smell of manes comes from dangerous roads,

Someone from the other side of the border is unrealistic to come.

The angel at the Tulip funeral came and went,

Only the faint sound of rustling wings is heard...

(interlinear translation )

In this passage, Aminpour uses allegory and metaphor. The poet indicates by the expression: "dangerous roads" are the roads of the war, i.e. in times of war borders are closed, no communication. During the war Angel has to come to the funeral ceremony, as there are many dead. An angel comes to the funeral of the "Tulip", the Tulip of the poet represents youth, beauty, in other words, Qeysar states the fact that in the war the majority of young people die, the beauty and the future of the nation perishes.

Essentially, his poetry was evolving and prone to flexibility, which distinguishes it from the works of his contemporaries. His first collection of poems was the book "Breath of the morning" ("Tanaffos-e sobh"), which was published in 1984. In this collection Qeysar Aminpour is presented as a sensual and emotional poet, prone to descriptive style. The theme of his poems is mostly war, the glorification of the victims and martyrs of the revolution, the praising influential personalities of the revolution, etc. 
In another collection of Qeysar Aminpour entitled "On the Sunny street" ("Dar kuche-ye aftab"), published in 1984, there is a deepening and development of religious, revolutionary, Patriotic and social reflections of the poet and praise to the victims of the revolution. The collection "On the Sunny street" was written in conditions full of revolutionary events and war, so the poetry is full of inner agitation.

Poetic work "the Afternoon of the tenth day" ("Zohr-e ruz-e dahom ") was published in 1986. It has a small volume - only 27 pages. This work is written in the style of "Nimah" and its main feature is that it is written on the theme of "Ashura" (this way the Shia Muslims called the day of remembrance of Imam Hosseyn, grandson and legitimate heir of the prophet Muhammad, martyred in 680 in the city of Karbala). Similar to traits, $\mathrm{r} / \mathrm{s}$ (religious and spiritual) variables describe dynamic mental and behavioral processes; however, $\mathrm{r} / \mathrm{s}$ constructs are unique in that they concern a person's perceived relationship with some form of transcendent reality-perhaps referred to as the Sacred or the Divine (Hill \& Pargament, 2003). [8].

\section{Summary}

Sacred Defense poetry is an array of poetic works dedicated to the Iran-Iraq war. This branch of art of the Islamic Revolution appeared with the onset of the Iran-Iraq conflict and the creation of an aura of heroism and a huge emotional tension around it. The poem "The Book of the Battle for Qeshm", the novel "The Burned Earth", and most of the poems by Salman Harati and Sepid Kashani are good examples of this type of Persian literature. The worlds changes leads changes in poetry. Globalization leads to the structural change of the modern world [Strohminger, 2014; Zeighami, \& Bahmaei, 2016; Zhatkin, 2018] and literature.

\section{Conclusions}

Iran's poetry of the 1980 s responded primarily to those phenomena and events that played a crucial role in the life of the country as the Iran-Iraq war. Revolutionary poetry can be described as a mixture of epics, mysticism and love for the Motherland. The revolutionary poetry of thought and the concept of "art for art" annulled and removed poetry and art from the framework of personal feelings to a wider scope and put them at the service of the great human, social, cultural, religious, ethical and national goal.

\section{Acknowledgements}

The work is performed according to the Russian Government Program of Competitive Growth of Kazan Federal University.

\section{References}

Akhmedova, M. (2018). Religious Vocabulary in Persian Poetry by Muhammad Iqbal. Herald National Academy of Managerial Staff of Culture and Arts, 2, pp. 280-283,.

Aminpur, K. (1969). Morning breathing, Tegeran, pp. 74. (in the Persian.lang.) 
Glushkova, S.; Lomakina, O. \& Sakulyeva, T. (2019). The economy of developing countries in the context of globalization: Global supply chain management. International Journal of Supply Chain Management, 8(Is.1), pp.876-884.

Kazimov, M. D. (2005). Persian poetry of the late XX century. Baku, pp. $36-37$.

Klyashtorina, V. B. (1975). Novaya poe’ziya» v Irane, M.: Nauka, Glavnaya redakciya vostochnoj literatury', P. 260.

Klyashtorina, V. B. (1990). Iran 60-80-x godov: ot kul'turnogo plyuralizma k islamizacii duxovny'x cennostej: (Ideologiya, politika, literatura), M.: Nauka. Glavnaya redakciya vostochnoj literatury', P. 207.

Manuchehr, A. (1993). Criticism and analysis of Islamic revolutionary literature. Part one. Tehran, pp. 17-, (in the Persian.lang.).

Mesto Kajsara Aminpura v sovremennoj poe`zii Irana http://cheloveknauka.com/mesto-kaysaraaminpura-v-sovremennoy-poezii-irana\#ixzz5px24Y8bK

Osobennosti poe ‘zii svyashhennoj oborony` v tvorchestve Kajsara Aminpura i Salmana Herati poe ‘zii «svyashhennoj oborony`» v tvorchestve Kajsara..., dislib.ruıFilologiya)...-kaysara-aminpura...

Psychology of Religion and Spirituality Personality, Religious and Spiritual Struggles, and WellBeing Joshua A. Wilt, Joshua B. Grubbs, Julie J. Exline, and Kenneth I. Pargament Online First Publication, January 21, 2016. http://dx.doi.org/10.1037/rel0000054

Qeysar, A. (1969). Morning breath, in Surush, Tehran, p. 74 (in the Persian.lang.).

Revolutionary literature, literary revolution. (1999). collection of articles of the Congress on the study of the influence of Imam Khomeyni and the Islamic revolution on modern literature. - Tehran: Imam Khomeini, $-1 \mathrm{~T}$. (in the Persian.lang.)

Salman, H. (2001). Full collection of poems by Salman Gerati: quire of new verses. S. Girati, Tehran. (In the Persian.lang.)

Strohminger, N. (2014). The essential moral self. 131(1), April, pp. 159-171. https://doi.org/10.1016/j.cognition.2013.12.005

Zaynullin, G. G. The role of spiritual and theological literature in Tatar culture of the XVIII and early XX centuries.

Zeighami, N., \& Bahmaei, R. (2016). Sociological study of structural and capital factors affecting the healthoriented lifestyle of over 15 year old citizens in Shiraz. UCT Journal of Social Sciences and Humanities Research, 4(3), 5-15.

Zhatkin, D. (2018). Russian literary-critical reception of Burns at turning of the XIX-XX centuries. Opción, 34(85-2), 277-300. 